\title{
Adsorption of Copper, Chromium, and Arsenic from Chromated Copper Arsenate (CCA) Treated Wood onto Various Adsorbents
}

\author{
S. Nami Kartal",, Coskun Kose ${ }^{1}$, B. Tarakanadha ${ }^{2}$ and Yuji Imamura ${ }^{3}$ \\ ${ }^{I}$ Forestry Faculty, Istanbul University, 34473 Bahcekoy Istanbul, Turkey \\ ${ }^{2}$ Indian Institute of Science, India \\ ${ }^{3}$ Research Institute for Sustainable Humanosphere (RISH), Kyoto University. Uji 611-0011, Kyoto, Japan
}

\begin{abstract}
Substantial progress has been made in remediation of preservative treated waste wood by chemical extraction with several mineral and organic acids and biodegradation using bacteria and fungi in recent years. Non-conventional low-cost adsorbents are used to bind the metal ions in extremely stable complexes in heavy metal contaminated soils or polluted waters and thus to remediate such substrates. In this study, various adsorbents from industrial and agricultural processes were evaluated in removal of copper, chromium, and arsenic from chromated copper arsenate (CCA)- treated wood by using batch extracting experiments. Most adsorbents used in the study had the potential to remove copper element from CCA-treated wood, while chromium was the most resistant element against removal in most cases. In general, as amount of adsorbents in the extraction process and extraction duration increased, the percentage of elements removed increased. The adsorbents used in the study could be important in the remediation of wood treated with organic or waterborne wood preservatives containing copper since the use of the adsorbents is one key to unfix copper from treated wood treated.
\end{abstract}

Keywords: Adsorption, adsorbents, copper, chromium, arsenic, CCA.

\section{INTRODUCTION}

Considerable research has concentrated on remediation of chromated copper arsenate (CCA) preservative treated wood in recent years due to release of chromium, copper, and arsenic from wood during recycling or disposal of such waste wood. As a result of public awareness about CCAtreated waste wood, substantial progress has been made in its remediation by chemical methods using mineral and organic acids and biological methods using bacteria and fungi in recent years [1-19]. However, such methods are becoming costly due to the cost of chemicals and nutrient media for fungal and bacterial cultures. Eliminating or reducing the cost of chemical or biological processes will make remediation of CCA-treated waste wood more economically and environmentally acceptable.

A number of approaches have been recently studied for the development of cheaper and more effective adsorbents for metal removal from several sources such as water and soil. Many non-conventional low-cost adsorbents, including natural materials, biosorbents, and waste materials have been proposed by several researchers. Most of the sorbents studied include agricultural wastes, industrial waste products, and biosorbents [20,21]. Natural materials available in large amounts and several agricultural and fishery waste products can be considered as effective and alternative technologies for the remediation of treated waste wood since these types of materials have the ability to retain toxic heavy metals

\footnotetext{
*Address correspondence to this author at the Forestry Faculty, Istanbul University, 34473 Bahcekoy Istanbul, Turkey; Tel: +90 2122261100 ; Fax: +90212 22611 13; E-mail: snkartal@istanbul.edu.tr
}

from aqueous solutions and potential as inexpensive adsorbents [19].

In this paper, activated carbon, sugi wood charcoal, extracted tea leaves, pine and oak tree bark, bakery yeast, apple and orange peelings, fungus biomass, pine cones, barley waste, and corn cobs were studied to determine their efficiency in removing chromium, copper, and arsenic from CCA-treated wood.

\section{MATERIALS AND METHODOLOGY}

\subsection{Adsorbent Materials}

The adsorbents used in the study are given in Table 1 along with their preparation for extraction.

\subsection{Preparation of CCA-Treated Chips}

Two Scots pine (Pinus sylvestris L.) poles were obtained from a preservative treatment plant in Adana, Turkey. The poles were previously treated with CCA Type C preservative solution using a full-cell process at a retention of $21 \mathrm{~kg} / \mathrm{m}^{3}$. Sapwood and heartwood portions of the treated poles were separated and the sapwood portions were then chipped with a commercial chipper to approximately $10-17 \mathrm{~mm} \times 0.20$ $0.35 \mathrm{~mm} \times 0.15-0.35 \mathrm{~mm}$. The chips were screened and sorted to remove knots and over/under sized chips. The chips were then conditioned at $23^{\circ} \mathrm{C}$ and $65 \%$ relative humidity (RH) for two weeks.

\subsection{Extraction of Chips}

Three g of CCA-treated chips were placed in $200 \mathrm{ml}$ distilled water together with each adsorbent in different amounts showed in Table 1 and extracted for $6 \mathrm{~h}, 1,2$, 5, and 
Table 1. Adsorbents Used in the Study and their Preparation for Extractions

\begin{tabular}{|l|c|l|}
\hline \multicolumn{1}{|c|}{ Adsorbents } & Amount in Extraction (g) & \multicolumn{1}{|c|}{ Preparation } \\
\hline \hline Activated carbon (AC) & $0.5,1,2,5,10$ & Used as it is \\
\hline Sugi wood charcoal (SC) & $0.5,1,2,5$ & $\begin{array}{l}\text { Sugi wood (Cryptomeria japonica) particles heated in a laboratory-scale electric } \\
\text { furnace with a heating rate of } 4{ }^{\circ} \mathrm{C} / \text { min up to a temperature of } 700^{\circ} \mathrm{C} \text { for } 1 \mathrm{~h} \text { in } \\
\text { presence of Ar as protective gas at a flow rate of } 100 \mathrm{ml} / \mathrm{min}\end{array}$ \\
\hline Extracted tea (ET) & $0.5,1,2,5,10$ & $\begin{array}{l}\text { Commercial black tea particles pre-extracted at } 80^{\circ} \mathrm{C} \text { in distilled water for } 1 \mathrm{~h}, \\
\text { dried at } 80^{\circ} \mathrm{C} \text { overnight }\end{array}$ \\
\hline Pine bark (PB) & $0.5,1,2,5,10$ & $2-3 \mathrm{~mm}$, dried at $80^{\circ} \mathrm{C}$ overnight \\
\hline Oak bark (OB) & $0.5,1,2,5,10$ & $2-3 \mathrm{~mm}$, dried at $80^{\circ} \mathrm{C}$ overnight \\
\hline Bakery yeast (BY) & 10 & $2-3 \mathrm{~mm}$, dried at $80^{\circ} \mathrm{C}$ overnight \\
\hline Apple peelings (A) & $0.5,1,2,5,10$ & $2-3 \mathrm{~mm}$, dried at $80^{\circ} \mathrm{C}$ overnight \\
\hline Orange peelings (O) & $0.5,1,2,5,10$ & $2-3 \mathrm{~mm}$, dried at $80^{\circ} \mathrm{C}$ overnight \\
\hline Fomes fomentarius dead biomass (F) & $0.5,1,2,5,10$ & $2-3 \mathrm{~mm}$, dried at $80^{\circ} \mathrm{C}$ overnight \\
\hline Pine cone (PC) & $0.5,1,2,5,10$ & $2-3 \mathrm{~mm}$, dried at $80^{\circ} \mathrm{C}$ overnight \\
\hline Barley waste (M) & $0.5,1,2,5$ & $\begin{array}{l}\text { Dried at } 80^{\circ} \mathrm{C} \text { overnight, obtained from Anadolu Efes Biracilik ve Malt Sanayii } \\
\text { A.S., Turkey }\end{array}$ \\
\hline Corn cob (C) & $0.5,1,2,5,10$ & $2-3 \mathrm{~mm}$, dried at $80^{\circ} \mathrm{C}$ overnight \\
\hline
\end{tabular}

10 days at room temperature. Distilled water extraction was served as control. Volumetric flasks containing distilled water, chips, and adsorbents were rotated at a speed of $100 \mathrm{rpm}$ (10.47 rad/s) during extraction. Two replicates of $3 \mathrm{~g}$ chips were removed at each time interval. The contents in the flasks were filtered through Whatman \#4 filter papers using a vacuum pump, and rinsed 3 times with $1 \mathrm{~L}$ of distilled water. Removed chips were oven-dried at $60^{\circ} \mathrm{C}$ for $24 \mathrm{~h}$ and conditioned at $23^{\circ} \mathrm{C}$ and $65 \% \mathrm{RH}$.

After extraction, chips were ground to pass a US Standard 40-mesh $(420 \mu \mathrm{m})$ screen to obtain sawdust. The sawdust samples from chips were then analyzed for copper, chromium, and arsenic content. Hundred mg of oven dried sawdust was transferred to a conical flask. The flask was gently heated on a sand bath without the loss of copper, chromium, and arsenic during the dissolution process, by adding approximately $10 \mathrm{ml}$ of nitric acid until sample was completely dissolved in acid.

The content of copper, chromium, and arsenic in liquid sample was analyzed using ICP Sequential Plasma Spectrometer (ICP-SII SPS 7800, Seiko Instruments Inc. Japan). The reduction percentage of copper, chromium, and arsenic in the treated chips was calculated at the initial amount of elements in the chips.

\section{4. pH of Extracted Chips}

A single homogenous sample of each type of extracted chip was analyzed for $\mathrm{pH}$. Before $\mathrm{pH}$ measurements, the chips were ground to pass a US Standard 40-mesh $(420 \mu \mathrm{m})$ screen to obtain sawdust. One part (by weight) of sawdust was then placed in three parts of distilled water. The sample and water were mixed until the sample was wet. $\mathrm{pH}$ was measured after $10 \mathrm{~min}$ at room temperature by using a digital $\mathrm{pH}$ meter.

\section{RESULTS AND DISCUSSION}

Results of ICP analysis for copper, chromium, and arsenic following extraction by the adsorbents of CCA-treated wood are shown in Table 2 . Figs. $(\mathbf{1}, \mathbf{2})$ show the percentage of copper, chromium, and arsenic removed from treated wood. Results are expressed as mg of each metal remaining per gram of treated wood following extraction. Values represent the average of duplicate samples. Exposing CCA-treated chips to various amounts of adsorbents enhanced removal of CCA components compared to remediation by distilled water only. Distilled water extraction removed considerably less amount of elements from the wood when compared to adsorbent extraction. As the amount of adsorbents in the extraction process and extraction duration increased, percentage removal of elements from CCA-treated wood generally increased.

Most adsorbents had a potential to remove copper element from CCA-treated wood, while chromium was the most resistant element against removal. On the basis of $10-$ day extraction duration, our study revealed copper removal hierarchies of bakery yeast $>$ oak bark $>$ apple peelings $>$ pine bark $>$ extracted tea $>$ dead biomass $=$ barley waste $>$ corn cob $>$ activated carbon $>$ orange peelings $>$ pine cone $>$ sugi wood charcoal. In most cases, copper removal was nearly $60 \%$ or more with a few exceptions of extractions with pine cone and sugi carbon. Highest arsenic removal rates were obtained with orange peelings, activated carbon and sugi wood charcoal. In general, the more adsorbent, the more removal rates we obtained in the study; however, in some cases increase in the amount of the adsorbent used causes slight decrease in removal rates. The reasons for this phenomenon are not clear; however, many variables in the process such as different concentrations of heavy metals in 
Table 2. Amount of Copper, Chromium, and Arsenic Remaining in CCA-Treated Chips Following Exposure to Various Adsorbents for 10 Days (mg/g)

\begin{tabular}{|c|c|c|c|c|}
\hline Source & Amount (g) & $\mathrm{Cu}$ & $\mathrm{Cr}$ & As \\
\hline \multirow{5}{*}{ Activated carbon } & 0.5 & 7.18 & 10.71 & 9.45 \\
\hline & 1 & 4.08 & 6.93 & 5.55 \\
\hline & 2 & 5.25 & 9.98 & 6.35 \\
\hline & 5 & 2.00 & 6.96 & 4.62 \\
\hline & 10 & 2.93 & 6.20 & 1.88 \\
\hline \multirow{4}{*}{ Sugi wood charcoal } & 0.5 & 4.95 & 7.94 & 6.89 \\
\hline & 1 & 5.67 & 9.26 & 4.71 \\
\hline & 2 & 5.31 & 6.45 & 4.66 \\
\hline & 5 & 5.22 & 7.13 & 2.80 \\
\hline \multirow{5}{*}{ Extracted tea } & 0.5 & 3.83 & 6.09 & 5.11 \\
\hline & 1 & 2.71 & 5.56 & 4.44 \\
\hline & 2 & 3.21 & 6.29 & 5.55 \\
\hline & 5 & 3.20 & 6.20 & 3.68 \\
\hline & 10 & 2.72 & 6.04 & 3.91 \\
\hline \multirow{5}{*}{ Pine bark } & 0.5 & 4.75 & 8.96 & 7.78 \\
\hline & 1 & 4.17 & 8.25 & 6.53 \\
\hline & 2 & 3.89 & 7.97 & 6.53 \\
\hline & 5 & 2.94 & 7.69 & 6.17 \\
\hline & 10 & 2.07 & 6.95 & 5.55 \\
\hline \multirow{5}{*}{ Oak bark } & 0.5 & 3.87 & 8.38 & 6.04 \\
\hline & 1 & 3.45 & 4.88 & 5.20 \\
\hline & 2 & 2.84 & 7.49 & 5.11 \\
\hline & 5 & 1.84 & 3.43 & 5.06 \\
\hline & 10 & 1.28 & 6.68 & 4.80 \\
\hline Bakery yeast & 10 & 0.68 & 8.38 & 6.22 \\
\hline \multirow{5}{*}{ Apple peelings } & 0.5 & 5.31 & 9.11 & 5.87 \\
\hline & 1 & 3.66 & 6.65 & 5.55 \\
\hline & 2 & 2.32 & 6.09 & 5.24 \\
\hline & 5 & 1.61 & 5.92 & 4.58 \\
\hline & 10 & 1.85 & 7.66 & 5.73 \\
\hline \multirow{5}{*}{ Orange peelings } & 0.5 & 3.60 & 7.05 & 5.48 \\
\hline & 1 & 3.28 & 6.40 & 5.55 \\
\hline & 2 & 3.66 & 5.61 & 4.53 \\
\hline & 5 & 3.16 & 7.01 & 4.98 \\
\hline & 10 & 3.00 & 6.12 & 1.70 \\
\hline \multirow{5}{*}{$\begin{array}{l}\text { Fomes fomentarius } \\
\text { dead biomass }\end{array}$} & 0.5 & 5.34 & 9.06 & 7.77 \\
\hline & 1 & 3.77 & 7.85 & 6.35 \\
\hline & 2 & 3.73 & 7.38 & 6.13 \\
\hline & 5 & 2.79 & 9.90 & 6.93 \\
\hline & 10 & 2.73 & 8.25 & 6.97 \\
\hline
\end{tabular}

\begin{tabular}{|c|c|c|c|c|}
\hline \multirow{2}{*}{ Source } & Amount (g) & $\mathbf{C u}$ & $\mathbf{C r}$ & $\mathbf{A s}$ \\
\hline \hline \multirow{4}{*}{ Pine cone } & 0.5 & 3.91 & 7.21 & 5.15 \\
\cline { 2 - 5 } & 1 & 3.65 & 6.85 & 5.78 \\
\cline { 2 - 5 } & 2 & 3.19 & 6.17 & 3.60 \\
\cline { 2 - 5 } & 5 & 4.14 & 7.46 & 4.93 \\
\hline \multirow{4}{*}{ Barley waste } & 10 & 3.47 & 7.41 & 5.60 \\
\cline { 2 - 5 } & 0.5 & 3.93 & 7.29 & 6.13 \\
\cline { 2 - 5 } & 1 & 3.84 & 7.69 & 6.35 \\
\cline { 2 - 5 } & 2 & 3.75 & 9.19 & 7.65 \\
\hline \multirow{3}{*}{ Corn cob } & 5 & 2.73 & 7.97 & 6.22 \\
\cline { 2 - 5 } & 0.5 & 4.27 & 7.46 & 5.95 \\
\cline { 2 - 5 } & 1 & 5.00 & 8.86 & 6.89 \\
\cline { 2 - 5 } & 2 & 3.35 & 6.29 & 5.64 \\
\cline { 2 - 5 } & 5 & 3.46 & 6.20 & 5.20 \\
\cline { 2 - 5 } & 10 & 2.82 & 6.68 & 5.42 \\
\hline
\end{tabular}

Values represent the average of duplicate samples. CCA-treated wood contained 9.8 $\mathrm{mg} / \mathrm{g}$ copper, $16.5 \mathrm{mg} / \mathrm{g}$ chromium, and $13.8 \mathrm{mg} / \mathrm{g}$ arsenic before extraction. $\mathrm{Cu}$ : copper; Cr: chromium; As: arsenic. Percentage removal rates for copper, chromium and arsenic elements during extraction with distilled water for 10 days rates were $27.7 \%$, $30.9 \%$, and $31.8 \%$, respectively.

treated wood, structure of the adsorbents, etc. may have played a role. Crini [21] states that activated carbon is the most popular adsorbent material for the removal of pollutants from wastewater [22-24]. Previous studies on remediation of heavy metal polluted soils suggest that copper is the most mobile metal in remediation studies. It is generally known that copper, chromium, and arsenic in CCA wood preservative are fixed to the wood components such as lignin and hemicelluloses by the reduction of $\mathrm{Cr}^{+6}$ to $\mathrm{Cr}^{+3}$ and chromium forms a strong complex with lignin. The reason for limited removal of chromium and arsenic may be that there is an strong affinity of these elements for wood components, and weak chelating ability of some adsorbents used on chromium and arsenic [12]. In a recent study on heavy metal removal from polluted soils by Abumaizar and Smith [25] chromium removal was found to be less due to the likelihood of chromium being in the anionic bichromate form compared to the other elements in the soil. Wasay et al. [26] found that EDTA was effective in removing copper from polluted soils, whereas removal efficiency of chromium was much less (30\%). Papassiopi et al. [27] states that arsenic, as an oxyanion in natural systems, does not form complexes with EDTA suggesting a slight mobilization, probably through the dissolution of related arsenate compounds. Several low solubility compounds formed during fixation reactions in CCA systems, such as chromium arsenate and copper arsenate, are found in CCA-treated wood structure like in metal-polluted soils. The covalent bonded or coordination bonded complexes of chromium occur with the wood lignin component is also another evidence [28, 29]. Formation of such complexes in CCA-treated wood could minimize the leaching of preservative components [12].

The $\mathrm{pH}$ of extracted wood with the adsorbents varied from 3.5 to 13.6 (Table 3). Values represent the average of 

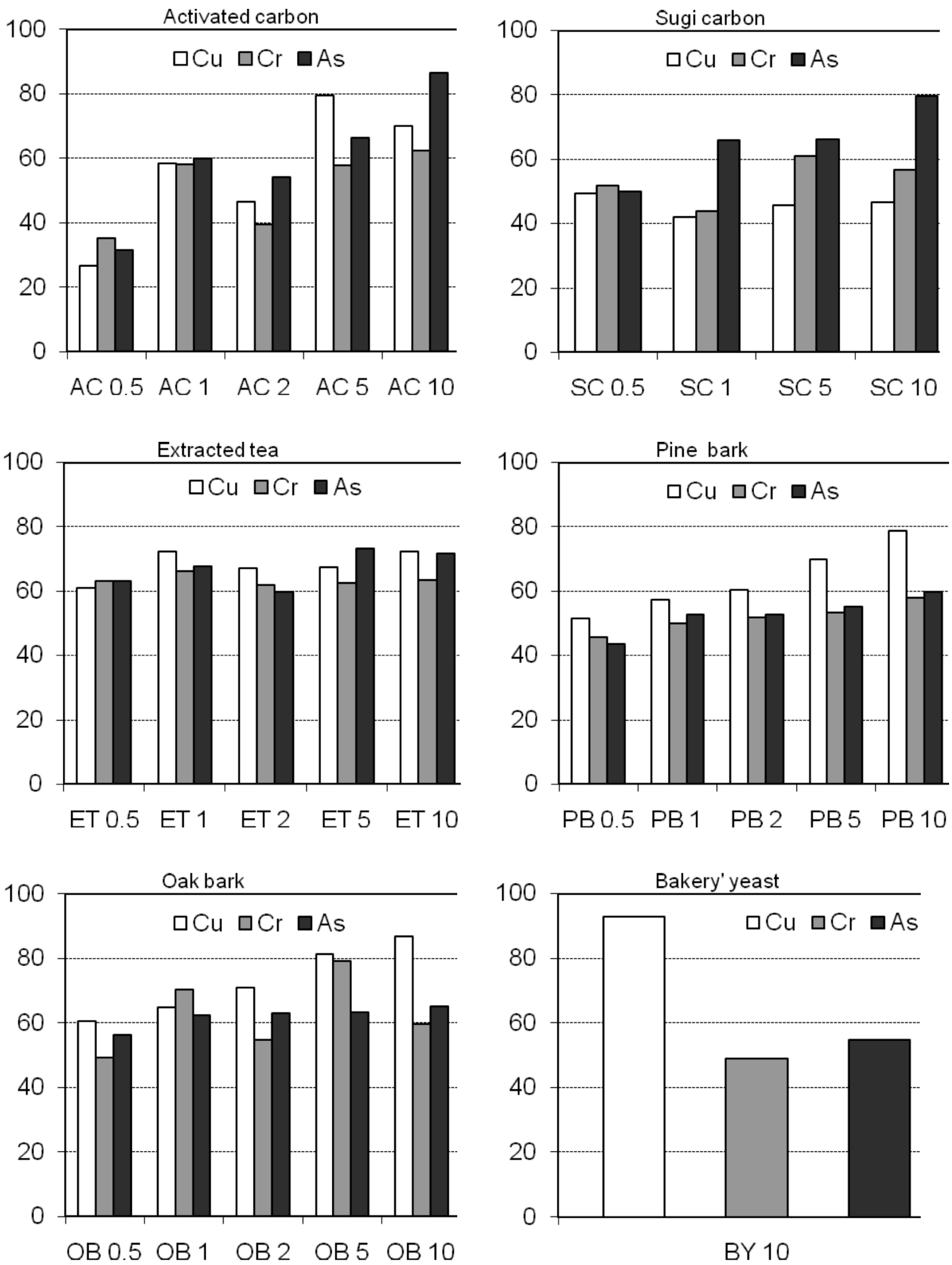

Fig. (1). Percentage of copper, chromium, and arsenic released following activated carbon, sugi wood charcoal, extracted tea, pine bark, oak bark, and bakery's yeast extraction of CCA-treated chips for 10 days. Cu: copper; Cr: chromium; As: arsenic. Refer to Table $\mathbf{1}$ for abbreviations. Percentage removal rates for copper, chromium and arsenic elements during extraction with distilled water for 10 days rates were $27.7 \%, 30.9 \%$, and $31.8 \%$, respectively. 

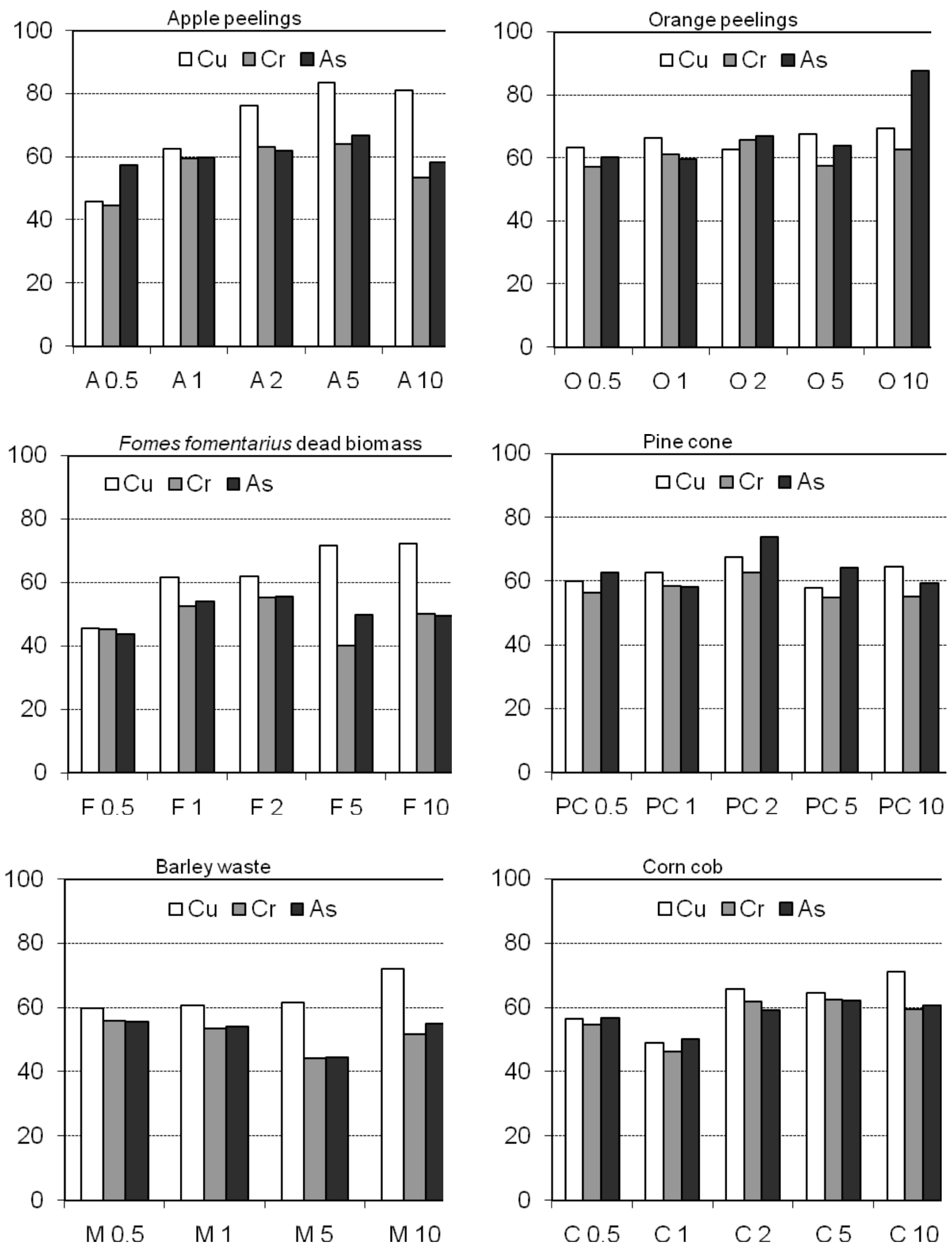

Fig. (2). Percentage of copper, chromium, and arsenic released following apple peelings, orange peelings, fungus biomass, pine cone, barley waste and corn cob extraction of CCA-treated chips for 10 days. $\mathrm{Cu}$ : copper; Cr: chromium; As: arsenic. Refer to Table 1 for abbreviations. Percentage removal rates for copper, chromium and arsenic elements during extraction with distilled water for 10 days rates were $27.7 \%$, $30.9 \%$, and $31.8 \%$, respectively. 
Table 3. pH of CCA-Treated Wood Following Exposure to Various Adsorbents

\begin{tabular}{|c|c|c|c|c|c|c|}
\hline \multirow{2}{*}{ Source } & \multirow{2}{*}{ Amount (g) } & \multicolumn{5}{|c|}{ Extraction Duration (Day) } \\
\hline & & $6 \mathrm{~h}$ & 1 & 2 & 5 & 10 \\
\hline \multirow{5}{*}{ Activated carbon } & 0.5 & 5.50 & 5.29 & 5.50 & 5.55 & 5.92 \\
\hline & 1 & 5.20 & 5.33 & 5.40 & 5.08 & 5.85 \\
\hline & 2 & 5.58 & 5.36 & 5.51 & 5.55 & 5.49 \\
\hline & 5 & 5.75 & 5.23 & 5.40 & 7.07 & 6.11 \\
\hline & 10 & 6.60 & 6.08 & 6.20 & 6.44 & 7.07 \\
\hline \multirow{4}{*}{ Sugi wood charcoal } & 0.5 & 6.59 & 5.22 & 5.38 & 5.20 & 5.30 \\
\hline & 1 & 5.50 & 5.39 & 5.13 & 5.45 & 5.16 \\
\hline & 5 & 5.42 & 5.49 & 5.45 & 5.63 & 5.44 \\
\hline & 10 & 5.28 & 5.35 & 5.35 & 5.81 & 5.43 \\
\hline \multirow{5}{*}{ Extracted tea } & 0.5 & 5.05 & 4.95 & 5.35 & 6.15 & 6.08 \\
\hline & 1 & 6.58 & 5.30 & 5.58 & 6.83 & 6.92 \\
\hline & 2 & 6.09 & 6.90 & 6.58 & 6.67 & 7.30 \\
\hline & 5 & 7.09 & 5.86 & 5.33 & 5.41 & 7.81 \\
\hline & 10 & 6.99 & 6.64 & 7.39 & 5.29 & 6.97 \\
\hline \multirow{5}{*}{ Pine bark } & 0.5 & 4.52 & 4.83 & 11.60 & 5.04 & 5.16 \\
\hline & 1 & 9.04 & 4.82 & 4.97 & 4.89 & 5.13 \\
\hline & 2 & 4.74 & 4.69 & 5.09 & 4.78 & 5.10 \\
\hline & 5 & 4.58 & 4.68 & 4.67 & 4.72 & 10.58 \\
\hline & 10 & 11.52 & 4.64 & 4.62 & 4.58 & 4.79 \\
\hline \multirow{5}{*}{ Oak bark } & 0.5 & 4.03 & 4.76 & 4.86 & 5.11 & 5.18 \\
\hline & 1 & 4.78 & 4.92 & 4.87 & 4.97 & 5.15 \\
\hline & 2 & 4.77 & 4.71 & 4.88 & 8.62 & 5.04 \\
\hline & 5 & 4.97 & 4.67 & 5.30 & 8.92 & 13.56 \\
\hline & 10 & 5.25 & 4.75 & 6.85 & 11.87 & 11.28 \\
\hline Bakery yeast & 10 & 6.08 & 6.21 & 7.17 & 8.97 & 7.45 \\
\hline \multirow{5}{*}{ Apple peelings } & 0.5 & 6.08 & 5.43 & 5.53 & 5.75 & 4.67 \\
\hline & 1 & 5.42 & 5.34 & 6.30 & 5.45 & 4.07 \\
\hline & 2 & 5.44 & 5.12 & 5.32 & 5.05 & 4.67 \\
\hline & 5 & 5.09 & 5.25 & 5.34 & 5.01 & 4.95 \\
\hline & 10 & 5.62 & 5.20 & 5.36 & 5.38 & 5.42 \\
\hline \multirow{5}{*}{ Orange peelings } & 0.5 & 5.46 & 7.05 & 6.55 & 5.56 & 5.91 \\
\hline & 1 & 6.71 & 6.72 & 6.10 & 6.29 & 4.90 \\
\hline & 2 & 5.82 & 6.18 & 6.50 & 5.16 & 6.68 \\
\hline & 5 & 7.00 & 6.47 & 7.10 & 5.07 & 5.56 \\
\hline & 10 & 6.78 & 5.28 & 7.11 & 6.79 & 6.38 \\
\hline \multirow{5}{*}{$\begin{array}{l}\text { Fomes fomentarius } \\
\text { dead biomass }\end{array}$} & 0.5 & 6.55 & 7.00 & 7.33 & 5.55 & 7.11 \\
\hline & 1 & 6.13 & 6.33 & 5.08 & 7.32 & 6.76 \\
\hline & 2 & 7.00 & 5.28 & 7.03 & 7.21 & 6.75 \\
\hline & 5 & 6.59 & 5.89 & 6.03 & 6.50 & 5.85 \\
\hline & 10 & 6.13 & 7.16 & 7.60 & 7.60 & 9.13 \\
\hline
\end{tabular}

(Table 3) contd......

\begin{tabular}{|c|c|c|c|c|c|c|}
\hline \multirow{3}{*}{ Source } & \multirow{3}{*}{ Amount (g) } & \multicolumn{4}{|c|}{ Extraction Duration (Day) } \\
\cline { 2 - 7 } & & $\mathbf{6 h}$ & $\mathbf{1}$ & $\mathbf{2}$ & $\mathbf{5}$ & $\mathbf{1 0}$ \\
\hline \hline \multirow{3}{*}{ Pine cone } & 0.5 & 4.74 & 11.51 & 5.03 & 13.95 & 10.10 \\
\cline { 2 - 7 } & 1 & 12.34 & 11.58 & 12.70 & 4.97 & 8.15 \\
\cline { 2 - 7 } & 2 & 9.27 & 7.94 & 12.38 & 4.95 & 9.93 \\
\cline { 2 - 7 } & 5 & 12.58 & 4.87 & 11.91 & 4.67 & 12.82 \\
\cline { 2 - 7 } & 10 & 10.14 & 10.27 & 4.95 & 13.64 & 5.28 \\
\hline \multirow{3}{*}{ Barley waste } & 0.5 & 4.98 & 13.17 & 4.39 & 8.98 & 5.47 \\
\cline { 2 - 7 } & 1 & 12.49 & 9.88 & 5.37 & 8.21 & 5.42 \\
\cline { 2 - 7 } & 2 & 4.89 & 8.73 & 7.05 & 6.47 & 5.55 \\
\cline { 2 - 7 } & 5 & 4.94 & 7.45 & 6.05 & 5.31 & 10.56 \\
\hline \multirow{3}{*}{ Corn cob } & 0.5 & 4.41 & 4.70 & 4.14 & 5.44 & 4.28 \\
\hline & 1 & 4.00 & 3.88 & 4.19 & 4.19 & 4.24 \\
\cline { 2 - 7 } & 2 & 3.65 & 3.53 & 4.59 & 5.15 & 4.79 \\
\cline { 2 - 7 } & 5 & 4.36 & 5.06 & 4.28 & 4.03 & 4.32 \\
\hline & 10 & 4.63 & 4.24 & 5.27 & 5.20 & 4.78 \\
\hline
\end{tabular}

$\mathrm{pH}$ of CCA-treated and unextracted control wood $=4.85$. Values represent the average of duplicate samples.

duplicate samples. The $\mathrm{pH}$ of CCA-treated and unextracted control wood was 4.9. In general, pine and oak bark and corn cob materials caused less $\mathrm{pH}$ in comparison with unextracted CCA-treated wood; however, $\mathrm{pH}$ values of extracted wood with pine cones reached over $\mathrm{pH} 10$ in most cases. It may be concluded that the adsorbents used in the study had a mixing effect in $\mathrm{pH}$, whilst in most cases removing CCA wood preservative components $(\mathrm{pH}=2.04$ for $1 \%$ CCA-C treatment solution at $20^{\circ} \mathrm{C}$ ) during extraction caused increasing $\mathrm{pH}$ as the extraction duration and amount of adsorbents increased.

\section{CONCLUSIONS}

In this study, adsorbent extraction of copper, chromium, and arsenic from CCA-treated wood was studied using batch-extracting experiments. Activated carbon and sugi wood charcoal materials were more effective in removing arsenic element from CCA-treated wood. However, more arsenic was removed when orange peelings were employed in the extraction process when compared to activated carbon and sugi wood charcoal adsorbents. Chromium was in general most resistant element against removal during extractions since this element play a role in fixing copper and arsenic in wood cell components during CCA fixation reactions. The study shows that adsorbents from agricultural or industrial processes may be a viable agent for the enhanced removal of copper from CCA-treated wood waste. Adsorbent usage may be one key to unfix copper for remediation of wood treated with copper-based preservatives. The removal of chromium and arsenic was shown to be lower than that of copper in treated wood in this study. Thus, most abundant adsorbents used in this study could be important in the remediation of waste wood treated with the newest formulations of organometallic copper compounds and other water-borne wood preservatives containing copper such as ammoniacal copper citrate, ammoniacal copper quat, oxine copper, copper naphthenate, copper azole, etc. The results of this study 
demonstrate that utilizing the adsorbents in the removal of copper from CCA-treated wood has potential; however, further research on extraction via repeated extraction cycles or dual remediation process using chemical remediation or bioremediation is needed to improve the removal efficiency of other CCA components.

\section{ACKNOWLEDGEMENTS}

Some data in this study have been compiled from unpublished B.Sc. theses by Miss. E. Alkan and Miss. S. Kucukacar completed at Forestry Faculty, Istanbul University under the supervision of the first author. The present work was supported by the Research Fund of Istanbul University. Project No: UDP-2011/23012008.

\section{REFERENCES}

[1] P. A. Cooper, "The potential for reuse of treated wood poles removed from service", International Research Group on Wood Preservation Doc. No. IRG/WP 93-50001. Stockholm, Sweden, 1993.

[2] C. C. Felton, and R. C. DeGroot, "The recycling potential of preservative-treated wood", Forest Prod. J., vol. 46(7/8), pp. 37-46, 1996.

[3] R. L Smith, and R. J. Shiau, "Steam processing of treated waste wood for CCA removal: Identification of opportunities for reuse of the recovered fiber", Report prepared for the Tennessee Valley Authority, Virginia Tech. and Hicksons Ltd. Virginia Tech. Blacksburg, VA, 1996.

[4] I. Stephan, R. D. Peek, and H. Nimz, "Detoxification of saltimpregnated wood by organic acids in a pulping process", Holzforschung, vol. 50, pp. 183-187, 1996.

[5] L. Helsen, E. V. Bulck, K. V. Broeck, and C. Vandecasteele, "Low temperature pyrolysis of CCA-treated wood waste: Chemical determination and statistical analysis of metal input and output, mass balances", Waste Manage., vol. 17(1), pp. 79-86, 1997.

[6] R. L. Smith, and R. J. Shiau, "Steam processing of treated wood for CCA removal: Identification of opportunities for re-use of the recovered fiber", Southeastern Regional Biomass Energy Program (SERBEP) of the Tennessee Valley Authority. Blacksburg, VA. Virginia Tech Dept. of Wood Sci. and Forest Prod., Center for Forest Prod. Marketing, 1997.

[7] C. A. Clausen, and R. L. Smith, "Removal of CCA from treated wood by oxalic acid extraction, steam explosion, and bacterial fermentation", J. Ind. Microbiol. Biotech., vol. 20, pp. 251-257, 1998.

[8] C. A. Clausen, "CCA removal from treated wood using a dual remediation process", Waste Manage. Res., vol. 18, pp. 485-488, 2000.

[9] C. A. Clausen, S. N. Kartal, and J. Muehl, "Properties of particleboard made from recycled CCA-treated wood", International Research Group on Wood Preservation, IRG/WP/00-50146, Stockholm, Sweden, 2000.

[10] C. Huang, and P. A. Cooper, "Cement-bonded particleboards using CCA-treated wood removed from service", Forest Prod. J., vol. 50(6), pp. 49-56, 2000.

[11] C. A. Clausen, S. N. Kartal, and J. Muehl, "Particleboard made from remediated CCA-treated wood: Evaluation of panel properties", Forest Prod. J., vol. 51, pp. 61-64, 2001.
[12] S. N. Kartal, "Removal of copper, chromium, and arsenic from CCA-C treated wood by EDTA extraction", Waste Manage., vol. 23, pp. 537-546, 2003

[13] S. N. Kartal, and C. Kose, "Remediation of CCA-C treated Word using chelating agents", Holz. Roh. Werkst, vol. 61, pp. 382-387, 2003.

[14] C. A. Clausen, "Improving the two-step remediation process for CCA-treated wood: Part I: Evaluating oxalic acid extraction", Waste Manage., vol. 24, pp. 401-405, 2004.

[15] T. Kakitani, T. Hata, T. Kajimoto, and Y. Imamura, "Effect of pyrolysis on solvent extractability of toxic metals from chromated copper arsenate (CCA) treated wood", J. Hazard Mater., vol. B109, pp. 53-57, 2004.

[16] T. Kakitani, T. Hata, T. Kajimoto, and Y. Imamura, "Two possible pathways for the release of arsenic during pyrolysis of chormated copper arsenate (CCA) treated wood", J. Hazard Mater., vol. 113(1-3), pp. 247-252, 2004.

[17] S. N. Kartal, E. Munir, T. Kakitani, and Y. Imamura, "Bioremediation of CCA-treated wood by brown-rot fungi Fomitopsis palustris, Coniophora puteana, and Laetiporus sulphureus", J. Wood Sci., vol. 50(2), pp. 182-188, 2004.

[18] S. N. Kartal, T. Kakitani, and Y. Imamura, "Bioremediation of CCA-C treated wood by Aspergillus niger fermentation", Holz. Roh. Werkst, vol. 62, pp. 64-68, 2004.

[19] S. N. Kartal, and Y. Imamura, "Removal of copper, chromium, and arsenic from CCA-treated wood onto chitin and chitosan", Bioresour. Technol., vol. 96(3), pp. 389-392, 2005.

[20] S. E. Bailey, T. J. Olin, R. M. Bricka, and D. D. Adrian, "A review of potentially low-cost sorbents for heavy metals", Water Res., vol 33, PP. 2469- 2479, 1999.

[21] G. Crini, "Non-conventional low-cost adsorbents for dye removal: A review", Bioresour. Technol., vol. 97(9), pp.1061-1085, 2006.

[22] K. R. Ramakrishna, and T. Viraraghavan, "Dye removal using low cost adsorbents", Water Sci. Technol., vol. 36 pp. 189-196, 1997.

[23] F. Derbyshire, M. Jagtoyen, R. Andrews, A. Rao, I. Martin-Gullon, and E. Grulke, "Carbon materials in environmental applications", in Chemistry and Physics of Carbon, Vol. 27, L.R. Radovic, Ed. New York : Marcel Dekker, 2001, pp. 1-66.

[24] S. Babel, and T. A. Kurniawan, "Low-cost adsorbents for heavy metal uptake from contaminated water: a review", J. Hazard. Mater., vol. B97, pp. 219-243, 2003.

[25] R. J. Abumaizar, and E. H. Smith, "Heavy metal contaminants removal by soil washing", J. Hazard. Mater., vol. B70, pp. 71-86, 1999.

[26] S. A. Wasay, S. Barrington, and S. Tokunaga, "Organic acids for the in situ remediation of soils polluted by heavy metals: Soil flushing in columns", Water Air Soil Pollut., vol. 127, pp. 301-314, 2001.

[27] N. Papassiopi, S. Tambouris, and A. Kontropoulos, "Removal of heavy metals from calcareous contaminated soils by EDTA leaching”, Water Air Soil Pollut., vol. 109, pp. 1-15, 1999.

[28] P. A. Cooper, D. L. Alexander, and Y. Ung, "What is chemical fixation?" in Chromium-Containing Waterborne Wood Preservatives, Fixation and Environmental Issues, Madison, WI, USA. Forest Products Society, 1993.

[29] S. T. Lebow, "Leaching of wood preservative components and their mobility in the environment", Summary of pertinent literature, General Technical Report, FPL-GTR-93. USDA Forest Service. Forest Products Laboratory, Madison, WI, USA, 1996. 